\title{
Mineralogy, geochemistry and possible provenance of desert sand dunes from western Rub' al Khali area, southeastern Saudi Arabia
}

\author{
Asaad M.B. Moufti \\ Department of Mineral Resources and Rocks, Faculty of Earth Sciences, King Abdulaziz University, B.O. Box 80206, \\ 21589 Jeddah, Saudi Arabia. \\ E-mail: ambmoufti@hotmail.com
}

\begin{abstract}
The Rub' al Khali desert dune sands are major constitutes of the southern part of the Arabian Peninsula. The investigated dunes in the present work are located in its western extreme where they display three major forms (seif, sigmoidal and barchan) with distinct variations in size and unique homogeneity of mineral composition. The Rub' al Khali sand dunes in its western part are placed in the craton interior and based on the contents of Quartz-FeldsparsLithic fragments, they are originating from a recycled orogen in which intrusive, sedimentary and partly metamorphosed sources have contributed to the composition of the sands. The presence of minerals like clay minerals and amphiboles in the bulk composition of the dune sands supports the influence of granitic, granodioritic and schistose sources. They are all fine sand, moderately well sorted, nearly symmetrical to fine skewed and mostly mesokurtic. The heavy mineral fractions are dominated by a variety of amphiboles (winchite-riebeckite-richterite-arfvedsonite) in addition to cordierite.

The geochemistry of the Rub' al Khali dune sands show that the dune sands are associated with acid, felsic plutonic detritus linked to an active continental margin. Correlations between $\mathrm{Fe}_{2} \mathrm{O}_{3}, \mathrm{SiO}_{2}, \mathrm{Al}_{2} \mathrm{O}_{3}, \mathrm{TiO}_{2}, \mathrm{MgO}$, and other oxides in the dune sands indicate the presence of ilmenite, magnetite and zircon in the samples. With respect to the provenance, there are two possibilities which are the Zagros Mountains in Iran and the Sahara Desert in North Africa. Orientation of linear dunes in the Rub' al Khali area is controlled by the dominant shamal (north) wind.
\end{abstract}

Keywords: sand dunes, Rub' al Khali, maturity, provenance, wind direction.

\section{Introduction}

Around one third of the Arabian subcontinent is covered by sandy deserts. The largest of these is the Rub' al-Khali, the Empty Quarter of Arabia, the world's largest erg (sand sea) (Fig. 1). It is the largest continuous expanse of sand desert on earth and occupies about $640,000 \mathrm{~km}^{2}[1,2]$. At present there are no permanent lakes in the Arabian Peninsula as potential annual evaporation exceeds inputs of precipitation and run-off. The most abundant dated evidence for palaeoenvironmental conditions during the Quaternary from the Arabian Peninsula comes from fossil lakebeds (for example, [3]). In general, these tend to occur in interdune areas.

The Rub' al Khali is a sedimentary basin elongated in a SW-NE direction across the Arabian Shelf, falling over a distance of about $1,000 \mathrm{~km}$ from an elevation of about $800 \mathrm{~m}$ in the south-west almost to sea level in the north-east.

According to [4], $\delta^{13} \mathrm{C}$ isotope, pollen and phytolith analyses indicate that $\mathrm{C} 3$ Pooid grassland with a strong woody element existed during the early Holocene (between 8500 and $6000 \mathrm{cal}$. yr BP) and became replaced by mixed C3 and C4 grasses with a strong C4 Panicoid tall grass element between 5900 and 5400 cal. yr BP. An intense, arid event occurred at $4100 \mathrm{cal}$. yr BP when the lake desiccated and was infilled by Aeolian sand. From $4100 \mathrm{cal}$. yr BP the vegetation was dominated by $\mathrm{C} 4$ Chloridoid types and Cyperaceae, suggesting an incomplete vegetation cover and Aeolian dune reactivation owing to increased regional aridity.

According to [5], the extreme aridity of the Rub' al Khali, its low ecological diversity and the absence of annual plants and sizeable trees are the main causes of the low numbers of both bird species (about 49) and individuals recorded, e.g. eagle owl, little owl, Hoopoe lark, brown-necked raven and house sparrow). Despite the extreme aridity of the Rub' al Khali, vegetation within the dunes is almost omnipresent, and unique in kind and composition; the sands of the region are more densely vegetated than the other less hyperarid rock deserts and gravels plains of the Kingdom. The shrub- 
dominated vegetation is very diffuse but is well distributed on the open sandy areas, interrupted by sterile interdune floors [5].

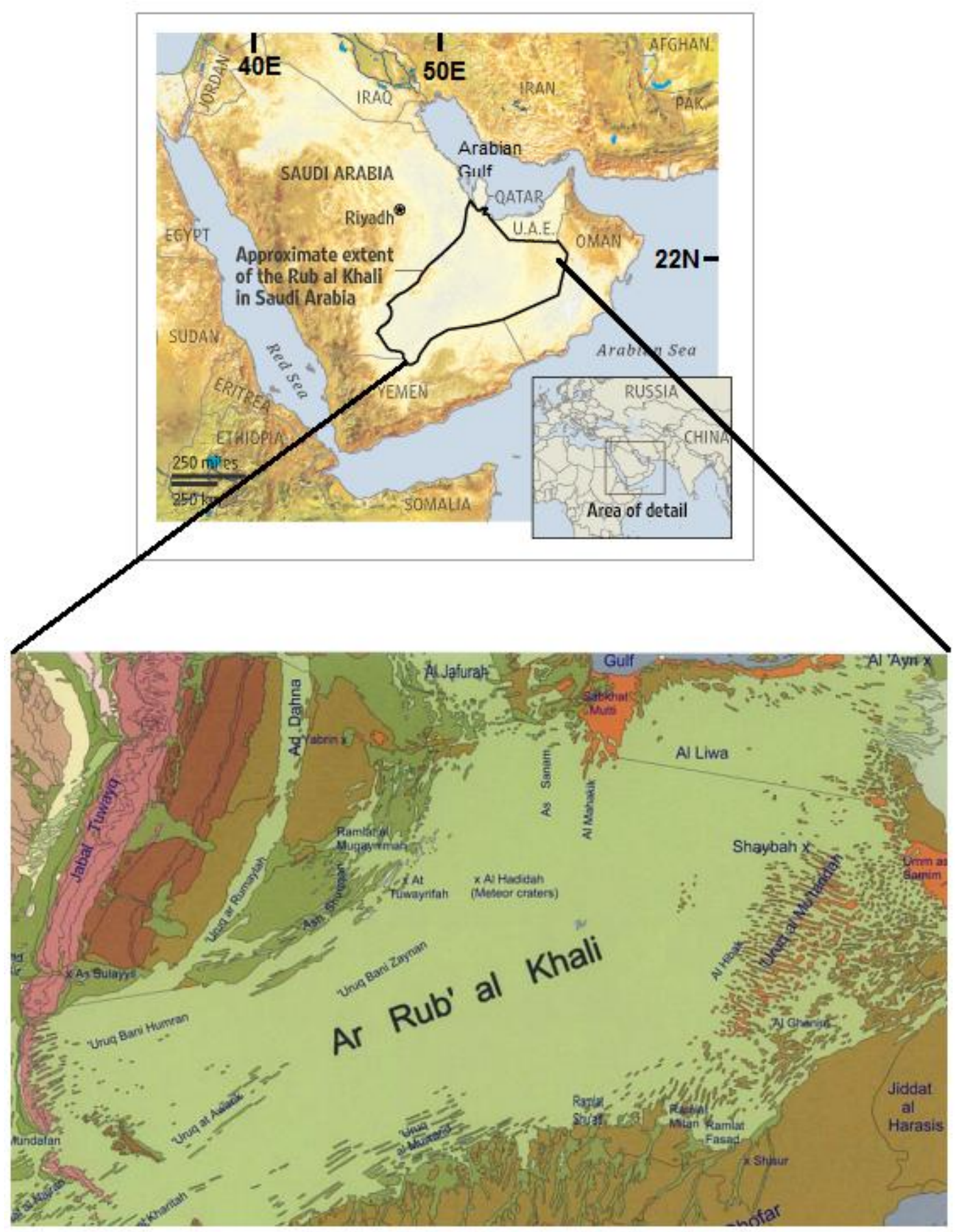

Fig. 1: Generalized map of the Ar Rub' al Khali (Empty Quarter) in the southern Arabian Peninsula. After [17].

Based on some recent geophysical investigations, there is a general flattening of the structure assuming the resemblance of a tilted monoclinal structure affected by faults [6]. Also, it was revealed that there is a possible presence of faults in sedimentary sequences which could represent the root causes of the near surface high-resolution seismic-gravity anomalies. Coastal and inland dune sands in desert environments are compositionally and texturally controlled by physical and chemical processes such as the wind action, marine/ fluvial processes, weathering, air temperature and precipitation [7,8]. Grain size variations in coastal and desert dune sands have been widely used to infer transport and depositional mechanisms $[9,10]$. For example, size coarsening of the dune sands may be due to wind deflation of fine 
grains leaving behind the coarse fraction in the sands [11]. It has been also observed that moderately to poorly sorted dune sands occur with short transport from the source of sediments to the dune systems [12]. In contrast, longer aeolian transport produces better sorted and fine-grained dune sands [10]. In addition, mineralogical and geochemical studies of dune sands provide new insights into the origin and evolution of aeolian sand bodies [7]. Quartz-rich sand dunes are mineralogically mature and they might have inherited their composition from quartz-rich sandstones and weathered plutonic and metamorphic rocks. Maturity of the sands might also be related to losses of labile minerals like feldspar grains due to ballistic impacts in high energy aeolian environments, chemical weathering of feldspar in soils, and fluvial size reduction of feldspars $[7,13]$. In contrast, feldspar-rich dune sands might be derived from feldspar-rich sources (arkosic sources) but also by little chemical weathering and short aeolian transport [7].

\section{Dune structures and morphology}

The great dune formations and accumulation of sediment are due to regularly occurring and powerful eolian systems on the Arabian steppe and in the Arabian Gulf region [14].

This analogue study examines and compares the geography of crescent megadune patterns for the Al Liwa basin of the Ar Rub' al Khali sand sea on the Arabian Peninsula. Fields of mega-barchanoid forms have shown the degree of selforganization to be largely an association between morphological diversity and dimensional variability. In short, fields of transitional mega-dunes (barchanoid seif) are comparatively less regular in distribution than are those fields, or part thereof, that consist of ubiquitous compound (barchanoid) morphologies whose patterns are more highly regular. The change in dune morphology, dimensions and spatial signature can, for the most part, be associated with the directional differences and varying intensities of the north-westerly Shamal and reversing south-westerly Kharif wind regimes [15] (Fig. 2).

Almost every dune shape is represented in the vast Rub' al-Khali. Even in the east only, there is a wide variety including barchans, megabarchans, pyramidal dunes, linear, sigmoidal complex, and hooked dunes [16]. The 'uruq (linear) are the most frequently occurring dunes in the entire desert, covering about $28.8 \%$ of it, and their frequency transcribes to the eastern region as well [17]. Commonly occurring on the 'uruq surfaces are smaller secondary dunes such as seif dunes, sigmoidal dunes, or barchans [17].

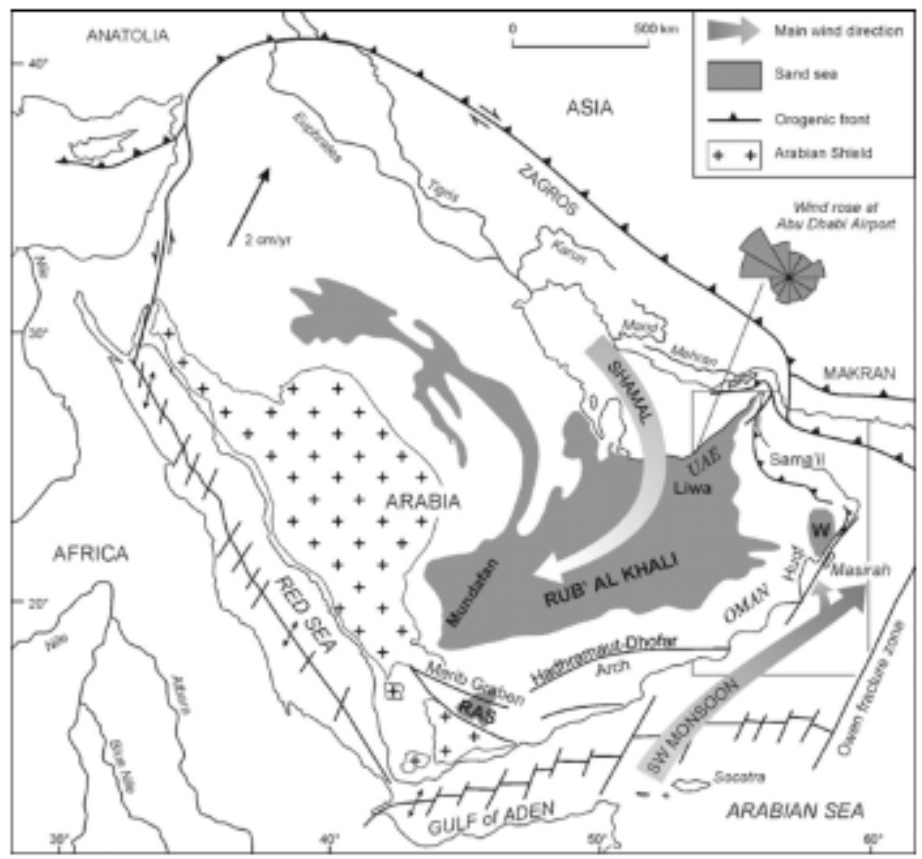

Fig. 2: Common wind directions in the Rub' al Khali and the rest of the Arabian Peninsula. After [14].

The highest dunes in the Rub' al-Khali are the megabarchans which can rise up to $230 \mathrm{~m}$ above interdune corridors. These megabarchans occupy about $38,000 \mathrm{~km}^{2}$ or $6 \%$ of the desert, but a significantly higher proportion in the east. There, they can especially be found concentrated around the 'Uruq al-Mu'taridah and 'Uruq ash-Shaybah areas [17]. They take the form of giant crescents with huge slip faces on their south or southeastern sides and are commonly between two and four $\mathrm{km}$ in length. Like 'Uruq, many secondary dunes form on the stoss sides of megabarchans like smaller barchans or sigmoidal dunes. 
Barchans and megabarchans can laterally link together to form barchanoid dune ridges. In addition, one of the most interesting dune formations are those of star dunes which may rise up to $180 \mathrm{~m}$ high and can be up to $2 \mathrm{~m}$ in diameter. Particularly widespread in the al-Ghanim region, these large solitary dunes form by the convergence of several dune ridges where winds beat about the compass until the dune becomes relatively stable [17].

\section{Methods and techniques}

As shown in Fig. 3, the material and data of the present studies were based on 13 bulk samples that have been collected from 13 stations in the Rub' al Khali desert. The samples were collected by one of the present authors (M.H. Basyoni) during a field campaign to the area in February 2013 by the Saudi Geological Survey (SGS).

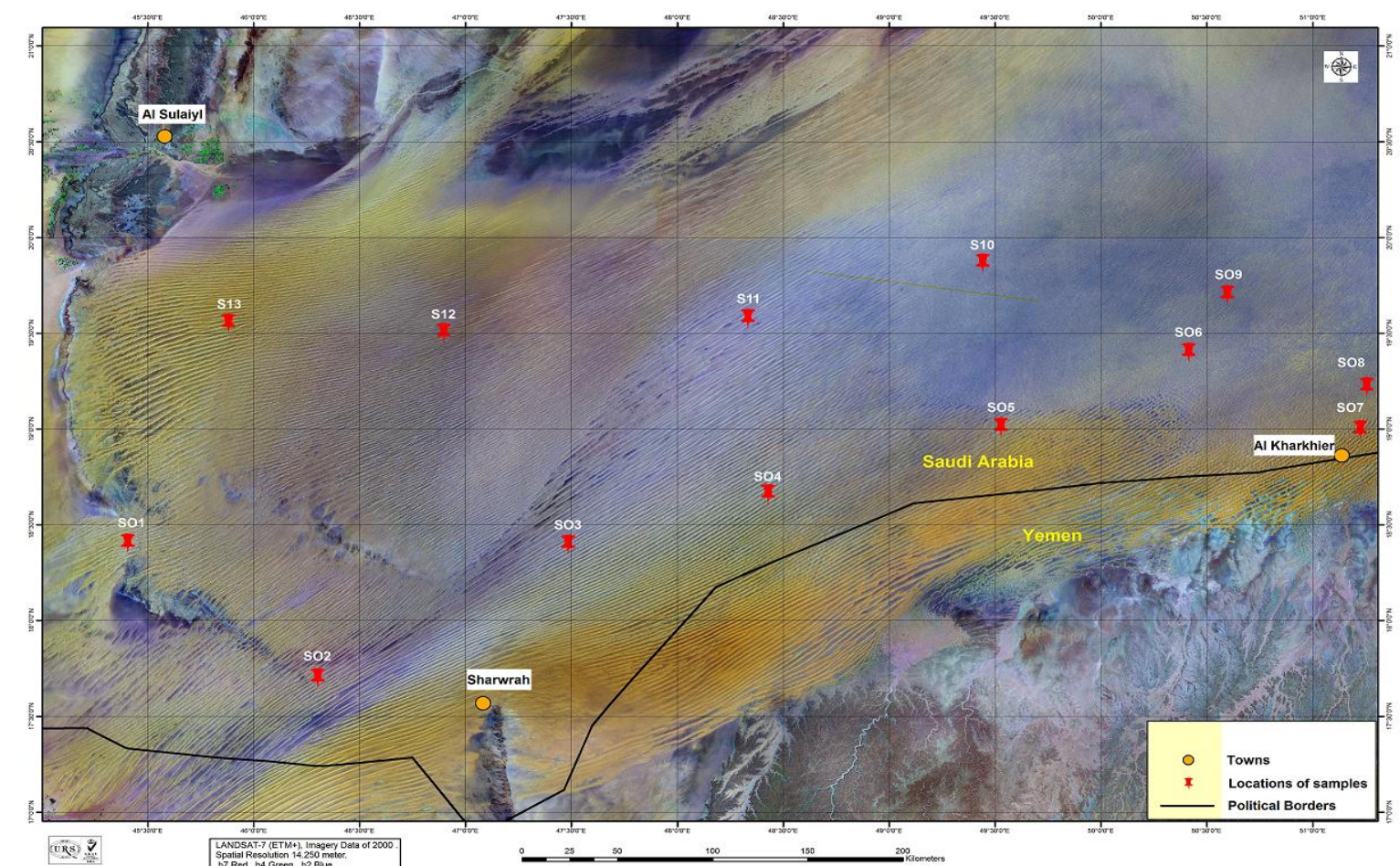

Fig. 3: Close view for the location of the investigated Rub' al Khali area in southern Arabian Peninsula. Stations are arranged following a route from 1 to 13 during a campaign by the Saudi Geological Survey, SGS in February 2103.

The samples were subjected to mechanical analysis and separation of heavy minerals by heavy liquids and isodynamic magnetic technique. Each fraction (light and heavy mineral concentrate) were subjected to X-ray diffraction analysis (XRD) in order to have a good information about the mineral composition of the bulk and heavy mineral fractions. Also, all bulk samples were analyzed for their major oxide contents by the X-ray fluorescence technique (XRF) using Philips machines housed at Faculty of Earth Sciences, King Abdulaziz University in Jeddah.

\section{Mineralogical composition}

The sediment is light yellow to reddish yellow, being redder in the east where we're focusing due to a light coating of ferric oxide on grain surfaces. Those dunes in the north and east within about $100 \mathrm{~km}$ of the Arabian Gulf are much more calcareous, but the carbonates remain at secondary amounts, either as dolomite or calcite [18]. Even in the extreme northeast of the desert, the sediment is still quartzitic, with distinct deeper reddish shades.

Throughout most of the Rub' al-Khali, the sediment is predominantly siliceous, with up to $90 \%$ of it being quartz and the rest mainly feldspar [17]. In the east, however, there is less a disparity with monocrystalline quartz accounting for about $71-76 \%$, feldspar $14-16 \%$, and the rest being carbonate, chert, and metamorphic grains [14].

In the Rub' al Khali dune sands, velocity and frequency of the winds might transport magnetite and some other heavy minerals landward, where short aeolian transport enables the transport of heavy minerals from the source sediment to the dune system. Table 1 shows that the studied sand dunes from the western Rub' al Khali part are dominated by light minerals (97.77-99.1\%) and they are dominated by quartz and some traces of plagioclase, saponite and montimorillonite 
as the sole clay mineral (Fig. 4). On the other hand, heavy minerals never exceed $2.23 \%$ including opaque and nonopaque phases. After elimination of magnetic opaques (magnetite, hematite and ilmenite) it was found that amphiboles represent the major constituent of the heavy fractions. The amphiboles comprise riebeckite, winchite, richterite and arfvedsonite, and such species are enriched in Mn and Fe as indicated by their XRD patterns (Fig. 5). The heavy fractions include also zirkelite, ankerite and idialite where the latter is a high-T polymorph of cordierite that occurs commonly in contact metamorphic aureoles.

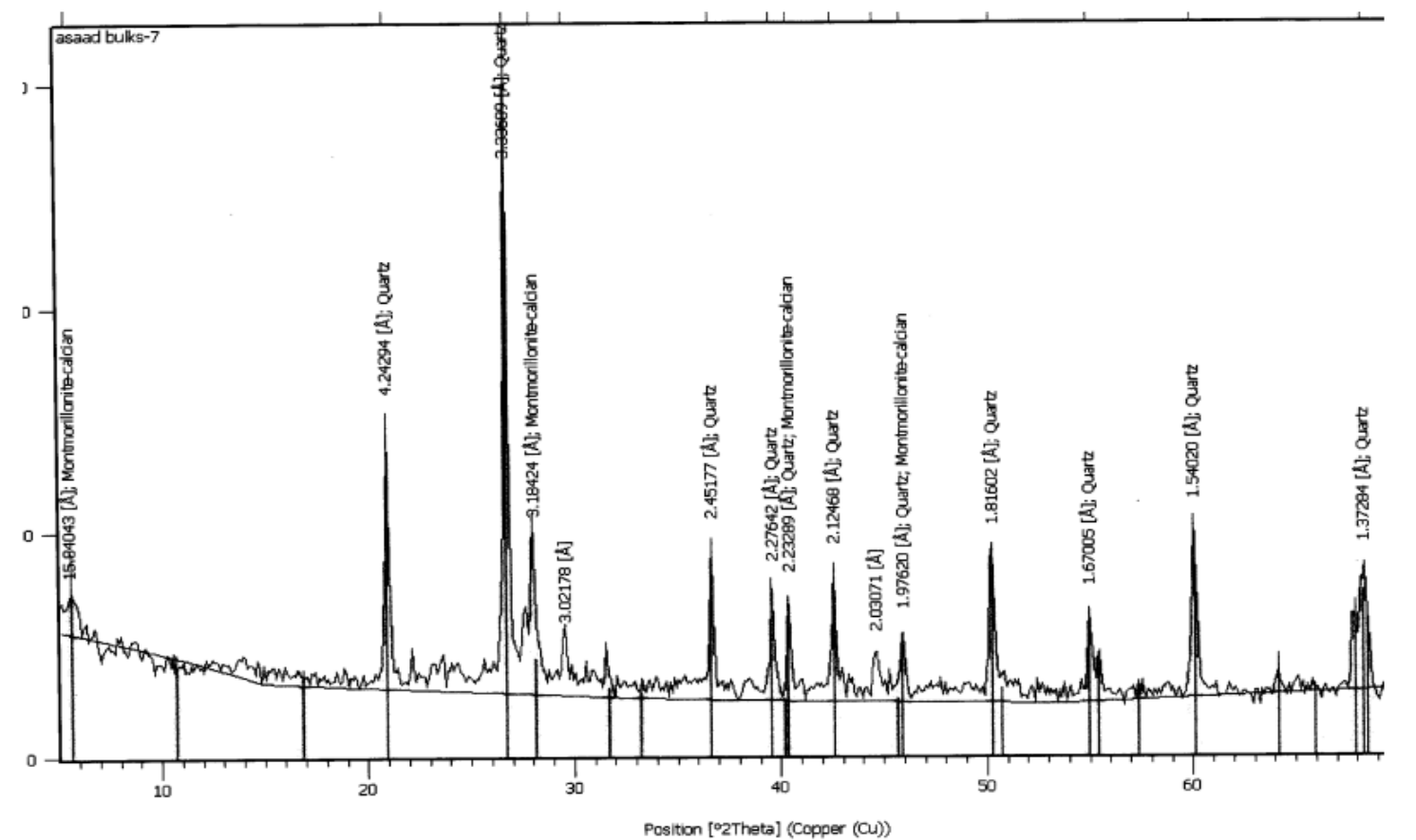

Fig. 4: XRD analysis of a representative bulk sample from the Rub' al Khali.

Table 1: Mineralogy and sieve analysis data of the studied dunes

\begin{tabular}{|c|c|c|c|c|c|}
\hline $\begin{array}{l}\text { Sample } \\
\text { No. }\end{array}$ & $\begin{array}{l}\text { Light } \\
\text { Minerals } \\
(\%)\end{array}$ & $\begin{array}{c}\text { Heavy } \\
\text { Minerals } \\
(\%)\end{array}$ & Major light minerals & $\begin{array}{l}\text { Major heavy } \\
\text { minerals }\end{array}$ & $\begin{array}{c}\text { Characteristics as obtained from } \\
\text { sieve analysis } \\
\text { (name, sorting skeweness, kurtosis) }\end{array}$ \\
\hline S-1 & 98.55 & 1.45 & $\begin{array}{l}\text { quartz-sapronite- } \\
\text { plagioclase }\end{array}$ & richterite-zirkelite & $\begin{array}{l}\text { fine sand: moderately well sorted, } \\
\text { nearly symmetrical \& mesokurtic }\end{array}$ \\
\hline $\mathrm{S}-2$ & 98.91 & 1.09 & quartz-plagioclase & riebeckite & $\begin{array}{l}\text { fine sand: well sorted, nearly } \\
\text { symmetrical \& mesokurtic }\end{array}$ \\
\hline $\mathrm{S}-3$ & 99.29 & 0.71 & quartz-montmorillonite & $\begin{array}{l}\text { fluoro-magnesian } \\
\text { arfvrdsonite }\end{array}$ & $\begin{array}{l}\text { fine sand: moderately well sorted, } \\
\text { fine skewed, \& mesokurtic }\end{array}$ \\
\hline $\mathrm{S}-4$ & 98.93 & 1.07 & quartz-saponite & ferriwinchite & $\begin{array}{r}\text { fine sand: very well sorted, nearly } \\
\text { symmetrical \& leptokurtic }\end{array}$ \\
\hline $\mathrm{S}-5$ & 98.56 & 1.22 & quartz-nontronite & $\begin{array}{l}\text { riebeckite- } \\
\text { ankerite-cordierite }\end{array}$ & $\begin{array}{l}\text { fine sand: moderately well sorted, } \\
\text { nearly symmetrical \& mesokurtic }\end{array}$ \\
\hline S-6 & 98.18 & 1.82 & quartz-saponite & ferriwinchite & $\begin{array}{l}\text { fine sand: well sorted, nearly } \\
\text { symmetrical \& mesokurtic }\end{array}$ \\
\hline $\mathrm{S}-7$ & 98.96 & 1.04 & quartz-montmorillonite & ferriwinchite & $\begin{array}{l}\text { fine sand: moderately well sorted, } \\
\text { nearly symmetrical \& mesokurtic }\end{array}$ \\
\hline S-8 & 97.85 & 2.15 & quartz-saponite & $\begin{array}{l}\text { magnesian } \\
\text { riebeckite }\end{array}$ & $\begin{array}{l}\text { fine sand: moderately well sorted, } \\
\text { nearly symmetrical \& mesokurtic }\end{array}$ \\
\hline S-9 & 97.77 & 2.23 & quartz-plagioclase & hastingsite & $\begin{array}{l}\text { fine sand: well sorted, nearly } \\
\text { symmetrical \& leptokurtic }\end{array}$ \\
\hline S-10 & 98.62 & 1.38 & quartz-plagioclase & richterite & $\begin{array}{l}\text { fine sand: moderately sorted, fine } \\
\text { skewed and platykurtic }\end{array}$ \\
\hline S-11 & 98.78 & 1.22 & $\begin{array}{l}\text { quartz-plagioclase- } \\
\text { montmorillonite }\end{array}$ & mangoan richterite & $\begin{array}{l}\text { fine sand: moderately well sorted, } \\
\text { nearly symmetrical \& mesokurtic }\end{array}$ \\
\hline S-12 & 98.56 & 1.44 & $\begin{array}{l}\text { quartz-plagioclase- } \\
\text { montmorillonite }\end{array}$ & ferriwinchite & $\begin{array}{l}\text { fine sand: well sorted, nearly } \\
\text { symmetrical \& mesokurtic }\end{array}$ \\
\hline S-13 & 99.91 & 0.19 & $\begin{array}{l}\text { quartz- } \\
\text { montmorillonite }\end{array}$ & $\begin{array}{l}\text { indialite (high-T } \\
\text { cordierite) }\end{array}$ & $\begin{array}{r}\text { fine sand: moderately well sorted, } \\
\text { fine skewed \& mesokurtic }\end{array}$ \\
\hline
\end{tabular}




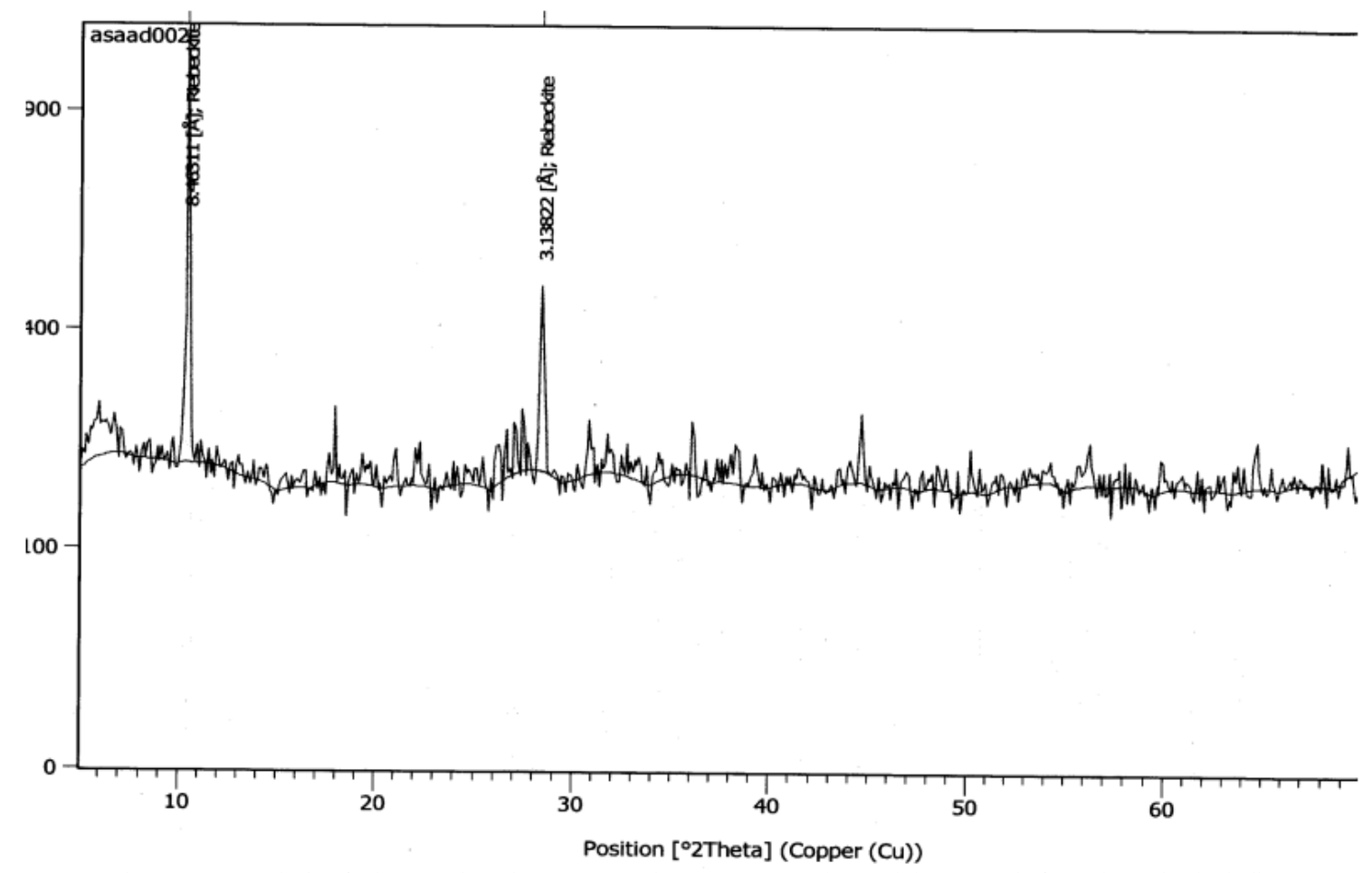

Fig. 5: XRD analysis of a heavy mineral concentrate that was separated a sand dune sample from the Rub' al Khali.

\section{Major oxides geochemistry}

The XRF analyses of whole-rock dsand dunes of 13 samples from the Rub' al Khali west are given in Table 2 . Correlations between $\mathrm{SiO}_{2}, \mathrm{Al}_{2} \mathrm{O}_{3}, \mathrm{TiO}_{2}, \mathrm{Fe}_{2} \mathrm{O}_{3}, \mathrm{CaO}, \mathrm{MgO}, \mathrm{K}_{2} \mathrm{O}, \mathrm{Na}_{2} \mathrm{O}$ and Loss on Ignition, LOI (Fig. 6 and Fig. 7 $\mathrm{a} \& \mathrm{~b})$ indicate the following: 1) the positive correlation suggests the presence of heavy minerals associated with sedimentary sources mainly ilmenite and magnetite [19-21],2) on the other hand, the negative correlation between $\mathrm{SiO}_{2}$ and $\mathrm{Al}_{2} \mathrm{O}_{3}$ indicates a considerable content of clay minerals as indicated by the XRD analyses too. The relatively high content of $\mathrm{CaO}-\mathrm{Na}_{2} \mathrm{O}$ in the Rub' al Khali dune sands is probably due to the slight enrichment of plagioclase feldspar. The A-B diagram (Fig. 7c) was plotted for different dune systems of the Rub' al Khali and other world examples for comparison, where $\mathrm{A}=\mathrm{SiO}_{2}$ and $\mathrm{B}=\mathrm{K}_{2} \mathrm{O}+\mathrm{Na}_{2} \mathrm{O}+\mathrm{Al}_{2} \mathrm{O}_{3}$. The Rub' al Khali dune sands are lower in $\mathrm{B}$ content compared to the Rice Valley dune sands in north America, but the Rub' al Khali is similar to the Algodones and Parker dunes and the Colorado River sediments [7,22]. In the case of the Rub' al-Khali dune sands, low B content is probably associated with the lack of mica in the sands. Low mica content in the Rub' al Khali dune sands indicates that wind direction and not its velocity exerts a control in the composition of the sands.

\section{Possible provenance}

The enrichment of quartz in both dune systems within the Rub' al Khali desert basin probably resulted from the maturity process, where the source rock might provide quartz-rich sediments. This interpretation is supported by 1) the presence of the alluvial deposits underlying the dune fields; 2) the composition of some of the rivers draining throughout the basin with moderately high quartz content; and 3) the high content of sedimentary lithics probably derived from sedimentary outcrops in the area, but also from the alluvial deposits that provides quartz detritus to the desert dune sands.

Following the quartz-feldspar-lithic fragments scheme of [23] is an indication of a craton interior and recycled orogen with tectonic fields suggesting intrusive, sedimentary and partly metamorphosed sources [23,24]. Maturation of the sands may be related to secondary processes as wind action leads to quartz-rich dune sands [7,22].

One theory which has stood the test of time fairly successfully posits that upwind highlands, undergoing heavy erosion before and during the Pleistocene, are the source of the Rub' al-Khali sediment. This sediment would be deposited in the Gulf, but would become available during glacial periods when sea level was much lower and more land and loose sediment was available for eolian transportation [25]. However, this theory did not specify any location and could not 
account for all sedimentation. Some speculated that eastern sediment was derived from the nearby Oman Mountains or from local Tertiary sandstones [26,17].

According to [16], these theories betray the groundless supposition that Arabia has been in isolation, ignoring the fact that high, greatly eroded mountains with calcareous and quartzose formations are right across the Gulf in the Zagros Range of Iran. This most compelling theory offers the most logical and comprehensive guide to Rub' al-Khali sediment provenance. Indeed, mineralogical studies of Quaternary sand dunes in the U.A.E. confirm that the source of sand was most likely the Tertiary fold belt of the Zagros and the Oman Mountains [27]. It seems most definite that at times of greater precipitation, the Zagros Mountains and other highlands of the Iranian plateau were heavily eroded and sediment carried by the Tigris, Karun, and other rivers into the Gulf. The dunes of the Rub' al-Khali, especially in the north and northeast, would then be formed mainly during intervals of low sea level when sediment from the dry Arabian Gulf would easily be carried by winds greater than today's [17]. Different formations in the Zagros confirm the likely probability of that range being the chief source of Empty Quarter sediment.

Most scientists place the creation of the sand seas in the Pleistocene - it's just a matter of when in the epoch, variations ranging in the hundreds-of-thousands of years [18]. The latter authors placed the sands of the extreme northeast of the desert in the latest Pleistocene and earliest Holocene and said that it happened during a single, rapid accretionary phase. Landsat images and heavy mineral concentrations were used to conclude that the Desert Sahara in northern Africa as the major source of sand dunes in the Arabian Peninsula [28]. On the other hand, [29] used the heavy-mineral suites to conclude that the sand of the eastern extension of the Rub' al Khali came mostly from the ultramafic rocks that form the ophiolitic sequence of the Oman Mountains, the acidic rocks of Iran and from the Precambrian Arabian Shield.

Table 2: Major oxides of the studied dunes (bulk samples as determined by XRF technique).

\begin{tabular}{|l|c|c|c|c|c|c|c|c|c|c|c|c|c|}
\hline $\begin{array}{l}\text { Sample } \\
\text { No. }\end{array}$ & $\mathrm{S}-1$ & $\mathrm{~S}-2$ & $\mathrm{~S}-3$ & $\mathrm{~S}-4$ & $\mathrm{~S}-5$ & $\mathrm{~S}-6$ & $\mathrm{~S}-7$ & $\mathrm{~S}-8$ & $\mathrm{~S}-9$ & $\mathrm{~S}-10$ & $\mathrm{~S}-11$ & $\mathrm{~S}-12$ & $\mathrm{~S}-13$ \\
\hline $\mathrm{SiO}_{2}$ & 92.22 & 89.8 & 91.66 & 89.84 & 90.38 & 84.13 & 85.89 & 83.45 & 83.89 & 88.34 & 88.9 & 89.15 & 94.93 \\
\hline $\mathrm{TiO}_{2}$ & 0.28 & 0.22 & 0.2 & 0.22 & 0.25 & 0.3 & 0.23 & 0.37 & 0.32 & 0.28 & 0.26 & 0.2 & 0.1 \\
\hline $\mathrm{Al}_{2} \mathrm{O}_{3}$ & 2.25 & 3.76 & 3.11 & 4.35 & .5 .12 & 5.82 & 4.34 & 5.37 & 5.56 & 3.48 & 3.82 & 3.99 & 1.58 \\
\hline $\mathrm{Fe}_{2} \mathrm{O}_{3}$ & 1.26 & 1.14 & 0.86 & 1.09 & 1.7 & 1.81 & 1.13 & 1.7 & 1.89 & 1.41 & 1.21 & 1.21 & 0.82 \\
\hline $\mathrm{CaO}$ & 1.02 & 0.69 & 0.57 & 0.79 & 1.24 & 1.79 & 2.26 & 2.31 & 2.01 & 1.58 & 1.02 & 1.65 & 0.37 \\
\hline $\mathrm{MgO}$ & 0.35 & 0.32 & 0.29 & 0.4 & 0.68 & 0.73 & 0.62 & 0.69 & 0.69 & 0.62 & 0.46 & 0.38 & 0.23 \\
\hline $\mathrm{MnO}$ & 0.02 & 0.02 & 0.02 & 0.02 & 0.02 & 0.03 & 0.02 & 0.03 & 0.03 & 0.02 & 0.02 & 0.02 & 0.01 \\
\hline $\mathrm{Na}_{2} \mathrm{O}$ & 0.37 & 0.6 & 0.52 & 0.78 & 1.04 & 1.28 & 0.92 & 1.16 & 1.24 & 0.67 & 0.66 & 0.83 & 0.28 \\
\hline $\mathrm{K}_{2} \mathrm{O}$ & 0.54 & 1.21 & 0.99 & 1.29 & 1.4 & 1.43 & 1.22 & 1.42 & 1.36 & 0.99 & 1.27 & 0.95 & 0.4 \\
\hline $\mathrm{P}_{2} \mathrm{O}_{5}$ & 0.03 & 0.01 & 0.01 & 0.01 & 0.01 & 0.01 & 0.01 & 0.01 & 0.01 & 0.01 & 0.01 & 0.01 & 0.01 \\
\hline $\mathrm{H}_{2} \mathrm{O}^{+}$ & 0.2 & 0.2 & 0.16 & 0.1 & 0.01 & 0.08 & 0.06 & 0.02 & 0.08 & 0.12 & 0.01 & 0.1 & 0.12 \\
\hline $\mathrm{H}_{2} \mathrm{O}$ & 0.98 & 0.79 & 0.66 & 0.92 & 1.23 & 1.67 & 2.03 & 1.93 & 1.71 & 1.49 & 1.08 & 1.23 & 0.76 \\
\hline Total & 99.52 & 98.76 & 99.05 & 99.81 & 98.58 & 99.08 & 98.73 & 98.46 & 98.79 & 99.01 & 98.72 & 99.72 & 99.61 \\
\hline
\end{tabular}

\section{Conclusion}

The Rub' al Khali dune sands are fine, well sorted, near symmetrical sands with mesokurtic distributions. This reflects that onshore wind frequencies and velocities produce fine-sized and well-sorted dune sands inherited from beach sands during short aeolian transport into the coastal and inland dunes.

The Rub' al Khali desert dune sands are placed in the craton interior and recycled orogen fields in the Q-F-L triangle, which suggest intrusive, sedimentary and partly metamorphosed sources have contributed to the composition of the sands. The presence of minerals like mica and hornblende in the bulk composition of the dune sands supports the influence of granitic, granodioritic and schistose sources. The presence of biogenic detritus and carbonates in the coastal dune sands suggests that they are derived from beach sand sources mixed with alluvial deposits, whereas the inland desert dune sands are derived from alluvial deposits derived from sedimentary, volcanic, schists and granitic and granodiorites.

The geochemistry of the Rub' al Khali dune sands show that the dune sands are associated with acid, felsic plutonic detritus linked to an active continental margin [30]. Correlations between $\mathrm{Fe}_{2} \mathrm{O}_{3}, \mathrm{SiO}_{2}, \mathrm{Al}_{2} \mathrm{O}_{3}, \mathrm{TiO}_{2}, \mathrm{MgO}$, and other oxides in the dune sands indicate the presence of ilmenite, magnetite and zircon in the samples. 

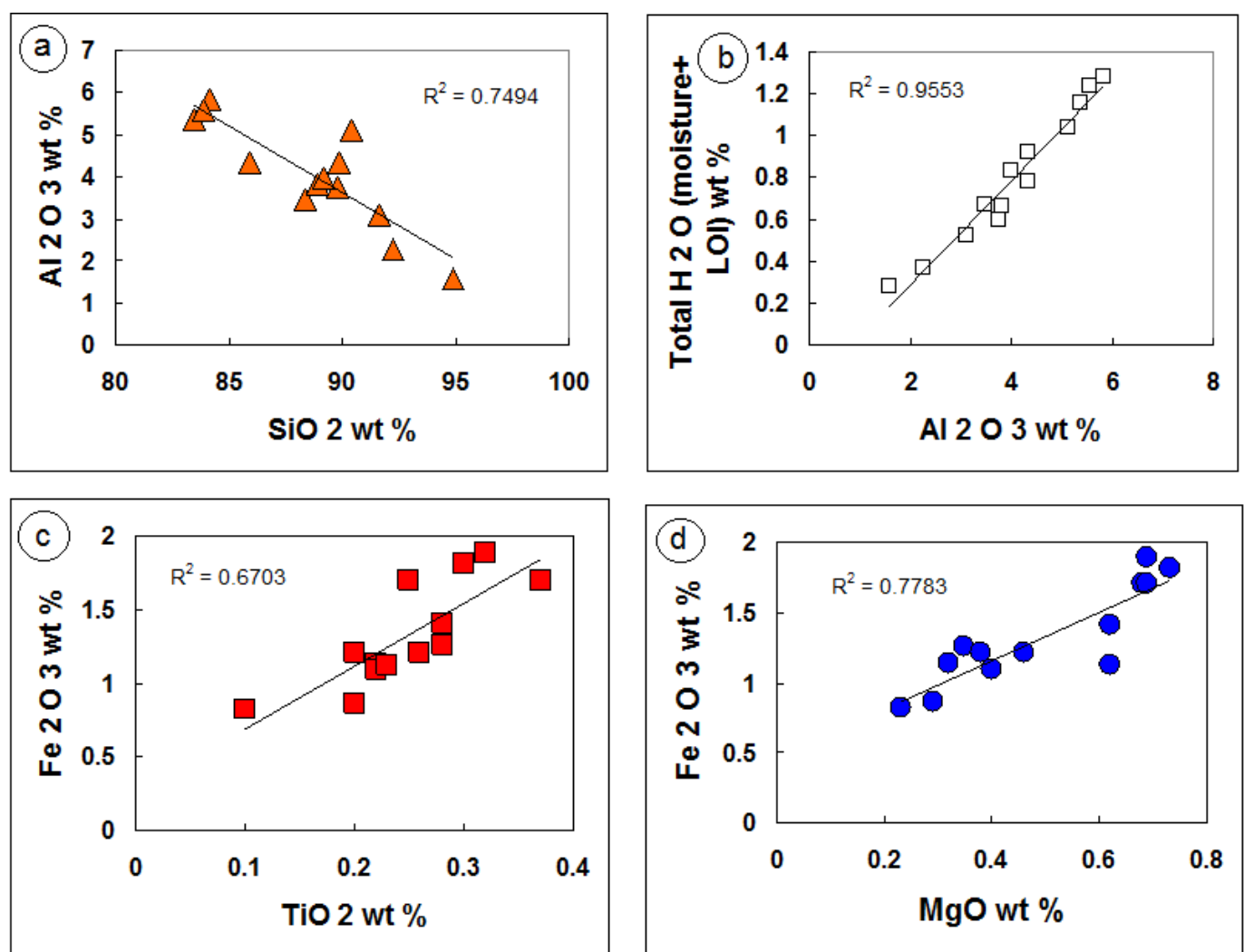

Fig. 6: a) Negative correlation between silica and alumina contents. b) Positive correlation between alumina and total water contents. c) Positive correlation between titania and Fe oxide contents. d) Positive correlation between magnesia and Fe oxide contents.
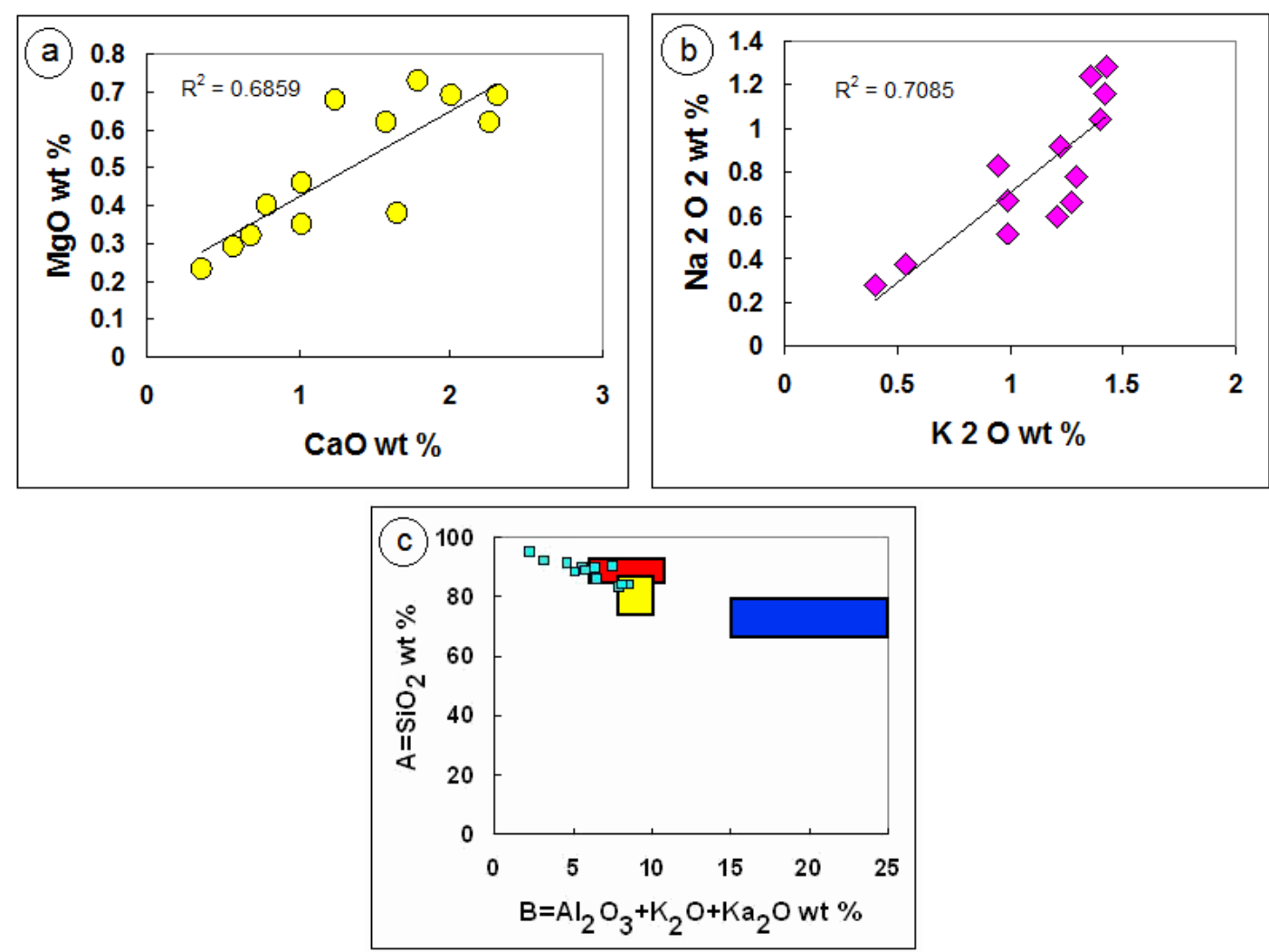

Fig. 7: a) Positive correlation between lime and magnesia content. b) Positive correlation between K and Na oxides. c) A vs. B diagram showing the trends of the Rub' al Khali sand dunes. For comparison with some world examples of sand dunes [7], the diagram also shows the range of samples from Rice Valley dunes (blue rectangle) and the Algodones and Colorado River sediments (yellow square) and Parker dunes (red rectangle). 


\section{Acknowledgements}

The author is greatly indebted for Prof. Mohamed Basyoni for his sincere help during collection of sand dune samples. The mechanical, mineralogical and geochemical analyses were generously conducted at the Faculty of Earth Sciences, Jeddah. Deep thanks are due to technicians and colleagues for their kind helps.

\section{References}

[1] I.G. Wilson, Ergs, Sedimentary Geology 10 (1973) 77-106.

[2] K. White, A.S. Goudie, A.G. Parker, A. Al-Farraj, Mapping the geography of the northern Rub' al-Khali using multispectral remote sensing techniques, Earth Surface Processes and Landforms 26 (2001) 735-748.

[3] A. Lézine, J. Saliège, C. Robert, F. Wertz, M. Inizan, Holocene lakes from Ramlat as-Sab'atayn (Yemen) illustrate the impact of monsoon activity in southern Arabia, Quaternary Research 50 (1998) 290-299.

[4] A.G. Parker, L. Eckersley, M.M. Smith, A.S. Goudie, S. Stokes, S. Ward, K. White, M.J. Hodson, Holocene vegetation dynamics in the northeastern Rub' al Khali desert, Arabian Peninsula: a phytolith, pollen and carbon isotope study, Journal of Quaternary Science, 19 (2004) 665-676.

[5] B. Pambour, A.R.A. Al Karriary, Notes on the birds of the eastern Rub' al Khali, Saudi Arabia, Sandgrouse 13 (1991) 80-91.

[6] D. Colombo, M. Mantovani, M. Sfolciaghi, P. van Mastrigt, A. Al-Dulaijan, N. Nafie, Near surface solutions in south Rub Al-Khali, Saudi Arabia applying seismic-gravity joint inversion and redatuming, First Break, Special Topic Middle East 28 (2010) 77-84.

[7] D.R. Muhs, Mineralogical maturity in dune fields of North America, Africa and Australia, Geomorphology 59 (2004) 247-269.

[8] M. Honda, S. Yabuki, H. Shimizu, Geochemical and isotopic studies of aeolian sediments in China, Sedimentology 51 (2004) $211-230$.

[9] X. Wang, Z. Dong, J. Zhang, J. Qu, A. Zhao, Grain size characteristics of dune sands in the central Taklimakan Sand Sea, Sedimentary Geology 161 (2003) 1-14.

[10] J.J. Kasper-Zubillaga, A. Carranza-Edwards, Grain size discrimination between sands of desert and coastal dunes from northwestern Mexico, Revista Mexicana de Ciencias Geológicas 22(2005) 383-390.

[11] F. Khalaf, Textural characteristics and genesis of the aeolian sediments in the Kuwaiti desert, Sedimentology 36 (1989) 253-271.

[12] G. Blount, N. Lancaster, Development of the Gran Desierto sand sea, Geology 18 (1990) 724-728

[13] D.R. Muhs, R.L. Reynolds, J. Been, G. Skipp, Eolian sand transport pathways in the southwestern United States: importance of the Colorado River and local sources, Quaternary International 104 (2003) 3-18.

[14] E. Garzanti, S. Ando, G. Vezzoli, D. Dell'era, From rifted margins to foreland basins: investigating provenance and sediment dispersal across Desert Arabia (Oman, U.A.E.), Journal of Sedimentary Research 73 (2003) 572-588.

[15] M.A. Bishop, nearest neighbor analysis of mega-barchanoid dunes, Ar Rub' al Khali, sand sea: The application of geographical indices to the understanding of dune field self-organization, maturity and environmental change. Geomorphology 120 (2010) 168-194.

[16] D. Buckler, The provenance, variety, and deposition of sediment and the formation of dunes in the eastern Rub' al-Khali, southeast Arabia, Sedimentology and Stratigraphy Research Paper May 1 (2008) 12 p.

[17] H.S. Edgell, Arabian deserts: nature, origin, and evolution, Springer, Dordrecht, The Netherlands, 2006.

[18] A.S. Goudie, A. Colls, S. Stokes, A. Parker, K. White, A. Al-Farraj, Latest Pleistocene and Holocene dune construction at the north-eastern edge of the Rub Al Khali, United Arab Emirates, Sedimentology 47 (2000) 1011-1021.

[19] A. Basu, E. Molinaroli, Provenance characteristics of detrital opaque Fe-Ti oxide minerals, Journal of Sedimentary Research 59 (1989). $922-$ 934.

[20] A. Carranza- Edwards, G. Bocanegra-García, L. Rosales-Hoz, L. de Pablo-Galán, Beach sands from Baja California Peninsula, México, Sedimentary Geology 119 (1998) 263-274.

[21] A. Carranza-Edwards, L. Centeno-García, L. Rosales-Hoz, R., Lozano-Santa Cruz, Provenance of beach gray sands from western México, Journal of South American Earth Sciences 14 (2001) 291-301.

[22] J.J. Kasper-Zubillaga, A. Carranza-Edwards, L. Rosales-Hoz, L., Petrography and geochemistry of Holocene sands in the western Gulf of Mexico: implications for provenance and tectonic setting, Journal of Sedimentary Research 69 (1999) 1003-1010.

[23] W.R. Dickinson, L.S. Beard, G.R. Brakenridge, J.L. Erjavec, R.C. Ferguson, K.F. Inman, R.A. Knepp, F.A. Lindberg, P.T. Ryberg, Provenance of North American Phanerozoic sandstones in relation to tectonic setting, Geological Society of America Bulletin 94 (1983) $222-$ 235 .

[24] J.S. Armstrong-Altrin, I.Y. Lee, S.P. Verma, S. Ramasamy, Geochemistry of sandstones from the Upper Miocene Kudankulam Formation, Southern India: implications for provenence, weathering and tectonic setting, Journal of Sedimentary Research 74 (2004) 285-297.

[25] D.A. Holm, Desert geomorphology of the Arabian Peninsula, Science, 132 (1960) 1369-1379.

[26] H. Besler, The north-eastern Rub' al Khali within the borders of the United Arab Emirates, Zeitschrift für Geomorphologie 26 (1982) 495 504.

[27] E.A. Ahmed, M.A. Soliman, A.S. Alsharhan, S. Tamer, Mineralogical characteristics of the Quaternary sand dunes in the eastern province of Abu Dhabi, United Arab Emirates. Balkema-Rotterdam, The Netherlands, 1998; 85-90.

[28] S.M. Awadh, Geochemistry and mineralogical composition of the airborne particles of sand dunes and dust storms settled in Iraq and their environmental impacts, Environmental Earth Sciences 66 (2012), 2247-2256.

[29] M.I. El-Sayed, The nature and possible origin of mega-dunes in Liwa, Ar Rub' Al Khali, UAE, Sedimentary Geology 134 (2000), $305-330$.

[30] J.J. Kasper-Zubillaga, H. Zolezzi-Ruiz, Grain size, mineralogical and geochemical studies of coastal and inland dune sands from El Vizcaíno Desert, Baja California Peninsula, Mexico, Revista Mexicana de Ciencias Geológicas 24 (2007) 423-438. 